\title{
Impact of Multinational Corporations on Economic Growth in Nigeria
}

\author{
Asma’u Aminu Abubakar \\ Department of Business Administration, Faculty of Management Sciences \\ Nile University of Nigeria, Abuja
}

\begin{abstract}
This research is an examination of the relationship between empirical analysis of the activities of multinational corporations and economic growth in Nigeria. The National bureau of statistics and CBN statistical bulletin were the sources of Secondary data used for the research. Appropriate Hypotheses were formulated and tested. The econometric tools of analysis employed was the unit root test and granger causality techniques. The Augmented Dickey Fuller (ADF) unit root test results show that all the variables were stationary. The granger causality test results indicated that a relationship exists between multinational corporations and economic growth. The study therefore recommends that Multinational corporations should ensure they uphold a green culture in the environment of their host country. It also recommends that Federal government should ensure that MNCs should empower host communities by providing scholarships to enable indigenes attain qualifications and skills that will enable them to be employed in the organization, while lower-level unskilled labor employment should also be provided.
\end{abstract}

Keywords: Multinational Corporations, Economic Growth, GDP, National Income.

DOI: $10.7176 / \mathrm{EJBM} / 13-6-11$

Publication date:March $31^{\text {st }} 2021$

\section{Introduction}

Multinational corporations (MNCs) have been in developing for countries and were driven mainly by policies of imperialism. Developing country especially Nigeria has played host to MNCs long before independence till date. These multinational corporations have grown their operations significantly over time and yet host countries still struggles for better life and socio-economic development (Onudogo, 2013). Aworom, 2013, is of the opinion that Multinational corporations are those great companies that came into being in Nigeria after the abolition of slave trade. The need for low-cost labor, market for production output and low-cost raw materials are driving forces for the inroads that industrialized countries of the world needed to propagate MNCs to underdeveloped countries. Nigeria seems to offer all these and more, which makes her an apparent target for MNCs. Consequently, MNCs like Shell, TotalFinaElf, ENI, Texaco Overseas, Pepsi, Coca-Cola, Lever brothers, amongst others dominate the Nigerian economy.

Nigeria is globally one of the largest producers of Oil, which accounts for over $85 \%$ of the foreign exchange earnings and over $60.1 \%$ of her total income. This sector is mainly dominated by MNCs which make enormous profit from their activities in the country. (CBN Bulletin, 2019). Ordinarily one should expect that such a country should not be plagued by underdevelopment, however the reverse is the case. In other more developed climes, MNCs have proven to be able to positively impact on the economies. For example, China, Korea, and Singapore have seen the presence of foreign investments to have helped in no small measure to boost their economies, resulting in increased domestic production and income levels. But this is not the case in Nigeria and majority of developing countries. This made led to the conclusion by many economists that MNCs are exploitative as they have failed to productively utilize such natural resources to the mutual benefit of all stakeholders especially the host countries. They rather focus on de-capitalization of the economy through profit repatriation (Osuagwu \& Ezie, 2013).

\subsection{Statement of Problem}

Odigwe (2019) averred that MNCs in Nigeria has had very positive and outstanding contributions to the country like technology transfer, increased investment, and higher income levels of the host communities to mention a few. The Nigerian economy has also seen a lot of benefits from MNCs especially the Oil and Gas industries. However, because of their vast resource base, MNCs have been able to displace indigenous industrialist through creation of monopoly. Likewise, Nigeria has the oil sector as the mainstay of the economy, with a huge presence of MNCs, these companies, however, perpetrate heinous activities such as involvement in local politics by promotion divide and rule policies, violation of human rights, pollution of the environment, inadequate technology transfer, poor discharge of adequate corporate social responsibilities, air, land, and sea environmental degradation especially in the Niger-Delta region without paying compensation adequately (Edem, 2004).

If left unabated, this situation has the potential to plunge the country into serious crisis as the presence and activities of these MNCs have resulted in an increase in anti-social activities like prostitution, drug abuses, fraud, 
kidnapping, murder and armed robbery amongst others, and it will only get worse. Eluka, Ndubuisi and Anekwe (2016) stated that Nigeria lost N2.46 trillion in 2006, N 2.69 trillion in 2007 and N2.97 trillion in 2008 through attacks on oil installations resulting in disruption and shutdowns and spillages in the activities of these Oil companies. Nigeria has also lost billions of dollars to foreign countries through act perpetrated by MNCs such as tax evasion, bribery, under-declaration of profit, over-invoicing, smuggling, and racketeering.

\subsection{Research Objectives}

The following objectives were formulated to drive this research:

i. To examine the relationship between the activities of Multinational Corporation and Gross Domestic Product in Nigeria.

ii. To ascertain the relationship between the activities of Multinational Corporation and National Income in Nigeria.

\subsection{Research Questions}

i. To what extent does the activities of Multinational Corporation influence Gross Domestic Product in Nigeria?

ii. How does the activities of Multinational Corporation affect National Income in Nigeria?

\subsection{Research Hypotheses}

i. There is no significant relationship between the activities of Multinational Corporations and Gross Domestic Product in Nigeria.

ii. There is no significant relationship between the activities of Multinational Corporation and National Income in Nigeria.

\subsection{Literature Review}

2.1 Conceptual Framework

\subsubsection{Multinational Corporation}

Multinational Corporation is a term that describes companies with a strong national identification. It consists of the parent company usually with the head office based in their home countries and subsidiaries, associates, and operational bases in other countries. According to Wilczynski, (2016), the parent company typically owns enough percentage of the company's share capital so as to exercise control; what this connotes is that overseas activities were an extension of its domestic functions while the home headquarters remains the decision-making center.

Rugman and Collinson (2019) prefer to use the term multinational enterprises, states that the difference the difference between Domestic Corporation and the $\mathrm{MNC}$ is that the former operates strictly within the geographical confines of a country while the later operates across country boundaries. According to the United Nations multinational corporation are those with activities of the companies transcend more than one nation. They assert that there are certain minimum qualifying criteria that define MNCs, such as the type of activity or the importance and level of the foreign component as a percentage of the total activity of an MNC. Such activities may refer to assets sales, production, employment, or profits of foreign branches and affiliates (UNCTAD, 2000).

Jones, 2016, describes MNCs as firms that own and control its actives in more than one country. Production and distribution goods and services takes place across national boundaries; this results in a spread of technology, ideas, tastes, and goods/services throughout the world; and they conduct their operations on a global scale. Strategically these MNCs maintain offices, factories and other operational facilities in different countries but maintain a centralized head office from where coordination of global activities take place. A large majority of MNCs are from a few countries, namely America, Japan, and Western Europe. Some examples of MNCs are BMW, Nike, Mr. Biggs, AOL, Dominos, Toyota, and Coca-Cola.

Some writers, such as Akerodolo (2010), Ikelegbe (2005), and Ogbgbo (2005) have described MNCs as critical weapons that can help fight the challenge of underdevelopment, they also are of the opinion that MNCAS are engines of development that contribute greatly to the growth and development of a several nations. Despite some negative and destructive practices such as over pricing of technology and under invoicing of exports, there are still some very useful and beneficial roles that improve the living conditions of the local and host communities and the improvement of the national economy. Andabai (2010) states that, MNCs have been seen as companies that own and manage business in more than one country. According to Omotola, (2006), an MNC can also be described as a business conglomerate that have its headquarters located in a developed country and one or more operational bases in other countries. Several MNCs exist in Nigeria operating in several sectors of the economy such as manufacturing, banking, automobile, hospitality, extractive industry etc. (Ake, 2018).

2.1.2 Gross Domestic Product (GDP)

Peru (2016) states that Gross Domestic Product (GDP) is used internationally for measurement of the output and performance of an economy. It can be defined as the total market value of all final goods and services produced 
within a country usually over a given period. it is one of the many measurement indices that provides information on the composition and value of output of goods and services in any country. Statistics of GDP are usually provided as a primary measurement referred to as the nominal GDP, also real/constant GDP which is a price inflation adjustment of the nominal GDP.

Antonio (2015) is of the opinion that GDP is a measure of "economic growth", and can also be described as being a direct indicator of the level of an economy's production of goods and services, it is calculated with inputs from various survey and statistical data which is derived from the prevailing prices of the goods and services included in its scope within the defined period. This means that quantitative information on the production of goods and services can be extracted from price data. GDP is typically used for comparative measurements by economists. According to Acemoglu (2014) the design of GDP allows it to measure the market value for all products and services within a country's geographic boundaries. Since the measurement is based on market prices, it therefore considers many aspects of society including those relating to economic well-being.

\subsubsection{National Income}

National income is the aggregate monetary value of all incomes earned by individuals, enterprises governments etc. National income may also be defined as the monetary measure of the net aggregates of all commodities and services accruing to the inhabitants of an economy during a year. Thus, the concept national income has different meanings. Akerodolo (2010)

Andabai, (2006) defined National Income as the total amount of income that a country makes from economic activities in a given year. This includes receipts for payments from all resources be it wages, interest, rent, and profits. National Income can be used to measure the growth (Economic Growth) and progress of a country.

According to Marshall (2015) "The labor and capital of a country acting on its natural resources produce annually a certain net aggregate of commodities, material and immaterial including services of all kinds. This is the true net annual income or revenue of the country or national dividend."

Kuznets (2013) defines national income as "the net output of commodities and services flowing during the year from the country's productive system in the hands of the ultimate consumers."

2.1.4 The Impact of Multinational Corporation on Economic Growth

From the above we have seen that Multinational Corporations (MNCs) are a very important and major stimulus and contributors to growth of economies in developing countries. Andabai, 2010 stated that the relationship between MNCs and its activities in Nigeria is the basis upon which the contributions to the development of Nigerian economy has been focused on. Low level of investments, relatively very low savings, and lack of managerial skills etc. are hallmarks of less developed countries such as Nigeria. Odogbor (2004). Edem (2004) states that, to stimulate development, Nigeria and indeed developing countries require the inward flow of resources from MNCs, developed countries and development partners. He also noted that, like other business ventures, MNCs are set up to maximize profit, therefore it becomes a question of tact and negotiation between MNCs and the developing countries to defend their positions while striving for mutual benefit of all stakeholders. Akerodolo (2010) avers that, due to its wide areas of operations and the huge levels of investments (usually in billions of dollars) the oil industry has become one of the largest and most important industries in the world, therefore its influence is palpable in almost all the countries of the world and cannot be ignored.

According to Odogbor (2004), the agricultural sector accounts for over seventy percent of the working population in Nigeria, while the public and private sectors of which the multinational corporations belongs accounts for the remaining thirty percent. The MNCs which fall under the private sectors and have been noted to generally pay their employees high salaries including provision of generous fringe benefits than domestic firms' hence the tendency is for most Nigerian to prefer working for such companies than the public section. Omotola (2006) stated that, significant employment opportunities for the citizens are created because of the activities of the MNCs in developing countries. MNCs might have well created employment opportunities, social benefits, and other advantages, they as well as have employed capital intensive technologies which are inconsistent and Inappropriate with the Factor Endowment of the third world countries Kodjo, (2010). But overall, it must be admitted that many Nigerians have benefitted from the advent of MNCs into the country as they have provided substantial employment and social benefits. Ake, (2018) noted that this has gone greatly alleviated the problems of unemployment in the country. Neil (2004), states that (i) income generated through employment (ii) royalties and taxes paid to the government by the MNCS are some of the contributions to the state.

Ikelegbe (2005) maintained that, the inflow of capital because of the activities if MNCs have a multiplier effect in the rest of the economy as it increases the buying power of employees who then patronize the local food vendor, who in turn patronizes the local former and so on. In this way they affect the local industries, Onuoha (2005) reaffirmed that, the remunerations offered by MNCs goes a long way to raise the standard of living and quality of life of the employees. Michael (2018) stated that, the income of the government is increased through royalties and project tax paid by MNCs as a result of their activities in the country. The MNCs have significantly contributed to the growth of the Nigerian economy and they dominate the private sector, and indeed oil and gas exploration, is a significant part of this sector. (Andabai, 2006). 
The multinational corporations contribute significantly to the growth of the economy and indeed dominates the private sector. Oil and Gas exploration is a chief contributor to the private sector. According to Andabai (2006), it is believed that, while MNCs promote national development, the level thereof is somewhat more an evidence of failures rather than achievement, therefore it has been ignored by most schools of thought. Awobajo (2006) reaffirmed this position by stating that, the overriding public opinions in Nigeria is that the operation of Oil and Gas companies has done more harm than good to the oil producing regions which are mostly in the Niger Delta region of the country. Nwosu (2008) concluded that, multinational Corporations especially the Oil and Gas companies have brought economic and social degradation in their host communities as a result are considered by those directly feeling the pains as agents of degradation and economic woes.

\subsection{Theoretical Framework}

This study is based on the new trade theory which was propounded by Tejvannne (2013). The theory explains the dynamics of growth of globalization with multinational corporations serving as main catalyst driving the growth. The theory posits that if government provide sustained support for new industries as well as existing ones over few years, such companies would be able to build economies of scale and become competitive in the long run without government support. It posits that an important factor in determining international patterns of trade are the network effects that can occur in key industries and the very substantial economies of scale that organizations are able to build. If further avers that network of effects and economies of scale are so important and significant that they override the more known and traditional theory of comparative advantage.

Osuagwu and Ezie (2013) Empirically examined the relationship between Multinational corporations and the Nigerian economy. Their work examined the ills of MNCs and how they have served as agents of imperialism in any economy where they operate, particularly amongst the host communities. Quite a lot of economists are of the opinion that the MNCs are exploitative as they tend to engage in de-capitalization of the economy in form of profit repatriation. The effect of this practice is that natural resources found in developing countries such as Nigeria are not productively utilized due for its development. It however argues that in spite of the negative activities of MNCs, they still contribute positively in the areas of employment generation and technological development.

\subsection{Empirical Studies}

Several studies, using different approaches, have established that multinational corporation have significant influence on economic growth. Some of those works are captured below.

The research work of Ewubare and Udofia, (2018) focused on the impact of MNC on economic growth in Nigeria. The study utilized secondary data obtained from the National Office for Technology Acquisition and Promotion (NOTAP) and the CBN statistical bulletins. The unit root test and granger causality techniques were the econometric tools of analysis employed. The granger causality test indicated that MNCs in oil and agricultural sectors have significant impact on economic growth, while MNCs in service sector does not have much impact on economic growth. The findings conclude that MNCs in both oil and agricultural sectors are key contributors to economic growth in Nigeria. The study therefore in addition to other things recommends that government should encourage more of MNCs in both oil and agricultural sectors by emplacing incentives, such as tax holidays and a favorable exchange policy in order to gain the advantage of technology transfer to Nigeria.

Shameema and Sahidur (2009) in their study of the impact of MNCs on Developing Countries noted some positive and negative impact of MNCs on economies of countries. They adopted regression methods and the result showed a statistically significant degree of association between exports and economic growth. Their study recommended that developing countries should aim at maintaining a year-on-year increase in FDI of at least $2.5 \%$ to attain one percent increase in economic performance.

Tonye and Andabai (2009), did an empirical analysis of the impact of MNCs on economic growth in Nigeria (1991-2014). The study was based on the CBN Bullentin from (1991-2014). The Secondary data were used and were collected from the CBN statistical bulletin and national bureau of statistics. Time series was the econometrics tool used in the study to test the formulated hypotheses. The study reveals that the variables do not have unit roots. Economic growth and multinational corporations showed a long-run equilibrium relationship which confirms that about $73 \%$ short-run adjustment speed from long-run disequilibrium. A causal relationship was established between MNCs and economic growth. About $52 \%$ of the variations in economic growth is explained by changes in multinational corporations' variables. The study went ahead to recommend that MNCs should in the provision of infrastructural facilities by way corporate social responsivities to the host communities. Host governments should mandate MNCs to reinvest a percentage their profits directly and deliberately to the development of the host communities as this will create a good working environment and improve security of the region. The Federal Environmental Protection agencies should also be alive to their responsibilities by ensuring proper monitoring of MNCs to avoid the MNCs violation of laid down rules and regulations. 


\subsection{Methodology}

This study adopted ex-post-facto research design. Secondary data obtained from Central Bank of Nigeria Statistical Bulletin (2008-2017) and National Bureau of Statistics were used. The fact that quarterly data were not be available for some of the variables prompted the study to use annual data. The ADF test and Granger causality tests were used by the study. The stationary of the time series was tested using the augmented dickey fuller test (ADF).

a. Test of Hypothesis

The Juselius (1990) and Johnsen's (1991) multivariate co-integration procedure was adopted by the study. Vector Error Correction Model (VECM) was used to test he co-integration:

$\Delta \mathrm{Yt}=\delta \mathrm{o}+\Sigma \delta \mathrm{i} \Pi \Delta \mathrm{Yt}-1+\Pi \beta \mathrm{Yt}-\mathrm{p}+\mu \mathrm{t}$

a $\quad b$

$\Delta \mathrm{Yt}=\Pi+\mathrm{i}=1 \Sigma \Pi \mathrm{i} \Delta \mathrm{t}-1+\Sigma \Pi \mathrm{i} \mathrm{t}-1+\Sigma \Pi \mathrm{it}-1+\Pi \mathrm{Rt}-1$

b

$\Delta \mathrm{GDt}=\Pi+\mathrm{i}=1 \Sigma \Pi \mathrm{i} \Delta \mathrm{SESt}-1+\Sigma \Pi \mathrm{i}$ COSt $-1+\Sigma \Pi \mathrm{i}$ OGSt-1 $+\Pi \mathrm{Rt}-1$

Where:

GDP $=$ Gross Domestic Product.

$\mathrm{SES}=$ Service Sector

COS $=$ Construction Sector.

OGS = Oil and Gas Sector

The VECM proceeds in the following manner, Pre-test for stationary, lag length, and test for co-integration and this is to ensure that the variables are stationary and that shocks are only temporary and will dissipate and revert to their long-run mean. The test for stationarity or unit roots employed for this study was the Augmented DickeyFuller (ADF) test which was performed on the variables at levels and first differences. Co-integration requires that all the variables be integrated of the same order and to test for unit roots, we used the ADF to test the null hypothesis of $\mathrm{H}$ o: $\mathrm{y} \alpha=0$ in

$$
\begin{aligned}
& \text { b }
\end{aligned}
$$

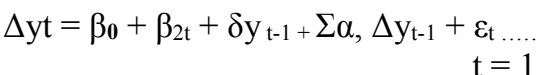

To examine whether a unit root exist the ADF test assumes the asymptotic normality of the idiosyncratic error term, et, in (4). The choice of lag-length may be decided using Sims likelihood ratio test and the appropriate lag length is important as too many lags reduce the power of the test due to the estimate of additional parameters and a loss of degrees of freedom. In contrast, too few lags may not capture the dynamics of the actual error correction process, resulting in poor estimates of growth and its standard errors.

\section{b. Data Analysis}

The Augmented Dickey-Fuller (ADF) unit root test statistics was used to test for stationarity; and to establish the order of integration of each. The null hypotheses of non- stationarity of oil and gas sector, construction sector and service sectors are tested against the alternative hypotheses. The results were presented in Table 1 which indicates that only gross domestic product (GDP) is stationary at levels while other variables are stationary after first differencing. However, all the non-stationary variables are stationary based on ADF critical values of 2.9558 at 5 percent level of significance and these imply that all the variables except gross domestic product is integrated of order one at levels.

Table 1. Unit Root Test Statistics.

\begin{tabular}{|l|l|l|l|c|}
\hline Variables & Levels & $\mathbf{1}^{\text {st }}$ Difference & Decision & Remarks \\
\hline G.DP & $-4.445217^{*}$ & & $1(0)$ & Stationary \\
\hline S.ES & -0.456831 & $-4.655482^{*}$ & $1(1)$ & Stationary \\
\hline C.OS & -1.642642 & $-3.525812^{* *}$ & $1(1)$ & Stationary \\
\hline O.GS & -2.258953 & $-6.756232^{*}$ & $1(1)$ & Stationary \\
\hline
\end{tabular}

Source: E-views Econometrics $5.0 *(* *)$ indicate statistical significance at the 1 percent and 5 percent level, respectively. The critical values at the 1 percent and 5 percent significance levels are -3.6956 and -2.9548 respectively and the critical values of ADF are from Mackinnon.

\section{Test for Co-integration}

Having found that all the variables are integrated, the next step is to perform Johansen co-integration procedure to ascertain whether oil and gas industry, construction industry and service industry are co-integrated. 
Table 2. Multivariate Johansen's Co-integration Test Result Lags interval: 1 to 2.

\begin{tabular}{|l|l|l|l|l|l|c|}
\hline $\begin{array}{l}\text { Null } \\
\text { Hypothesis }\end{array}$ & $\begin{array}{l}\text { Alternative } \\
\text { Hypothesis }\end{array}$ & $\begin{array}{l}\text { Eigen } \\
\text { value }\end{array}$ & $\begin{array}{l}\text { Likelihood } \\
\text { ratio }\end{array}$ & $\begin{array}{l}\text { Critical } \\
\text { values 5\% }\end{array}$ & $\begin{array}{l}\text { Critical } \\
\text { values 1\% }\end{array}$ & $\begin{array}{l}\text { Hypothesized } \\
\text { No. of CE(s) }\end{array}$ \\
\hline r $=0$ & r. $=1$ & 0.8586 & 64.9488 & 48.32 & 66.21 & None ** \\
\hline rd $<1$ & r. $=2$ & 0.7746 & 46.5646 & 37.40 & 41.52 & At most 1 \\
\hline rd $<2$ & r. $=3$ & 0.5608 & 25.8665 & 18.33 & 25.41 & At most 2 \\
\hline rd $<3$ & r $=4$ & 0.4765 & 187748 & 11.64 & 14.53 & At most 3 \\
\hline
\end{tabular}

Source: E-views Econometrics 5.0

Note: * (*) denotes rejection of hypothesis at $5 \%$ (1\%) significance level.

Vector Error Correction Model

The existence of long-run cointegrating equilibrium provides for short-run fluctuations and in order to straighten out or absolve these fluctuations, an attempt was made to apply the Error Correction model (ECM). The Error Correction coefficient contains information about whether the past values affect the current values of the variable under study. A significant coefficient implies that past equilibrium errors play a role in determining the current outcomes and the information obtained from the ECM is related to the speed of adjustment of the system towards long-run equilibrium and the short-run dynamics are captured through the individual coefficients of the difference terms.

Table 3. Vector Error Correction Estimates.

\begin{tabular}{|c|c|c|c|c|}
\hline Variables & Coefficient & Std. Error & t-Statistic & Prob. \\
\hline (EC.M-1) & -0.741542 & -0.424304 & 0.000881 & 0.011018 \\
\hline D(G.DP(-1)) & 0.145359 & -1.064548 & -0.000384 & 0.002628 \\
\hline D(G.DP(-2)) & 0.492761 & -3.865443 & 0.000163 & 0.008630 \\
\hline S.ES(-1) & 0.201340 & -0.97213 & 0.319891 & 0.18395 \\
\hline C.OS(-2) & 1.015441 & -0.611669 & $-2.73 \mathrm{E}-08$ & 0.000254 \\
\hline O.GS(-3) & 1.245979 & -0.643247 & $-5.57 \mathrm{E}-08$ & 0.000346 \\
\hline C & 0.483118 & -2.22149 & -1.48672 & 0.008760 \\
\hline R-sq.uared & 0.527335 & Mean depending var & & 0.015154 \\
\hline Adj. R-squ.ared & 0.501446 & S.D. depending var & & 0.335943 \\
\hline S.E. of re.gression & 4.010442 & Akaike Info. Criterion & & 5.865448 \\
\hline F-sta.tistic & 6.764455 & Schwarz criterion & & 6.305338 \\
\hline Log likelih.ood Prob. (F-stati.stics) & -147.57800 .000019 & Durbin-Watson Stat. & & 1.991435 \\
\hline
\end{tabular}

Source: E-views Econometrics 5.0

The negative sign observed in the error-correction coefficient indicates that it is statistically significant and confirms a necessary condition for co-integration of the variables.

Table 4. Result of Pairwise Granger-Causality Test (1991-2014) with 2-period Lag length.

\begin{tabular}{|l|c|c|c|l|}
\hline Null Hypothesis: & Obs & F-Statistic & Probability & \multicolumn{1}{|c|}{ Decision } \\
\hline GDP not Granger Caused by SES & 23 & 5.66318 & 0.00278 & Causality \\
\hline GDP not Granger Caused by SES & & 6.61528 & 0.04187 & Causality \\
\hline GDP not Granger Caused by SES & 23 & 8.85138 & 0.01876 & Causality \\
\hline GDP not Granger Caused by SES & & 7.87745 & 0.00065 & Causality \\
\hline GDP not Granger Caused by SES & 23 & 8.44766 & 0.02542 & Causality \\
\hline GDP not Granger Caused by SES & & 8.18674 & 0.02357 & Causality \\
\hline GDP not Granger Caused by SES & 23 & 5.65643 & 0.00855 & Causality \\
\hline GDP not Granger Caused by SES & & 6.44147 & 0.00656 & Causality \\
\hline GDP not Granger Caused by SES & 23 & 7.12753 & 0.01148 & Causality \\
\hline GDP not Granger Caused by SES & & 5.08713 & 0.00946 & Causality \\
\hline GDP not Granger Caused by SES & 23 & 7.34894 & 0.00636 & Causality \\
\hline GDP not Granger Caused by SES & & 6.06573 & 0.02024 & Causality \\
\hline
\end{tabular}

Note: The decision rule adopted for proof of causality is that if the estimated probability value is higher than the $5 \%$ or 0.05 level of significance, the null hypothesis is accepted, and vice versa.

c. Discussion of Findings

The results of the test are presented in Table 2. It shows that the null hypothesis has no co-integration with the variables (i.e. $r=0$ ) is tested against the alternative hypothesis for co-integration with the variables (i.e. $r=1)$. The null hypothesis is rejected at the $0.05(5 \%)$ significance level. The null hypothesis, however, $r=1$ could not be rejected against the alternative $r=2$ and $r=3$, this suggests presence of a unique co-integrating relationship among all the variables. It can therefore be concluded that a long-run relationship exists among the variables as shown by the likelihood ratio which is greater than the critical values at both $1 \%$ and $5 \%$ levels of significance. 
This indicate that a significant relationship exists between MNCs and GDP.

The study further indicates that the speed with which MNCs, especially Oil \& Gas, construction, and the service sectors, change from short-run dis-equilibrium to changes in National Income in order to reach a long-run equilibrium is $73 \%$ within 12 months. The coefficient of determination ( $22=0.527435)$ which shows a $52 \%$ of the variations in National Income. This can be explained by the changes seen in the variables of MNCs (S.ES, C.OS, O.GS) in the country (Nigeria). This implies that in Nigeria, a good percentage of National Income trends can be explained by the variables of MNCs. The 5\% significant F-statistics confirms the presence of an impact of MNCs on National Income.

\section{Conclusion}

It is therefore concluded that MNCs serve as the key driving force for stimulating economic growth with GDP and National income as the dimensions in developing countries like Nigeria. This is achieved through foreign direct investment; hence the study reveals that the variables of MNCs have no unit roots hence there is a long-run equilibrium relationship between economic growth and MNCs. The result confirms that about 0.73 (seventy-three percent) short-run adjustment speed from long-run disequilibrium and the coefficient of determination indicates that about 0.62 (sixty-two percent) of the variations in economic growth is explained by changes in the variables of MNCs.

\section{Recommendations}

The study recommends as follows:

- Multinational corporations should ensure they uphold a green culture in the environment of their host country by employing indigenes on the jobs and also make them part of the security personnel.

- Federal government should ensure that MNCs should empower host communities, by the provision of social amenities and low interest loans for small businesses.

- Federal government should ensure proper and adequate monitoring and supervisor of MNCs so that they do not violet the rights and privileges given to them.

\section{Future Research}

This study has made an immense scholarly contribution to the growing marketing/business literature. The study provides an in-depth investigation of the impact of multinational corporation on economic growth in Nigeria. To the academic community, this work serves as a reference material to scholarly students. The work is also of great importance to the Government and multinational business owners.

The study only adopted The Augumented Dickey Fuller (ADF) as the analytical tool. Thus, other scholars should endeavor to adopt other statistical tools and variables.

\section{References}

Acemoglu, M. (2014). Money, banking, international trade and public finance (7th ed.). Vrinda Publication.

Ake, H. (2018). The multinational corporations and development. A contraction in after and goodman (ed) the multinational corporations and social change. Freager.

Akerodolo, E. O. (2010). The underdevelopment of indigenous entrepreneurship in Nigeria. Ibadan University Press.

Andabai, P. W. (2010). The role of corporate social responsibility in an organization: A survey of some selected banks in Bayelsa state. International Journal of Social and Policy Issues, 4(1\&2), 162-175

Antonio, A. (2015). The macroeconomic effects of fiscal policy. Applied Economics, 44(34). 4439-4454.

Awobajo, S. A. (2006). Oil spillage in Nigeria 1978-1980 proceedings of the 1981. International Seminar. Lagos Nigeria.

Aworom, A. (2013). Multinational corporations and development in Nigeria. African Journal of Culture, Philosophy and Society, 3(1), 62-67.

Edem, A. (2004). The politics of conflicts over oil and gas in the Niger delta: The Bayelsa state Experience (Paper Presentation). University of Port Harcourt.

Eluka, J, Ndubuisi-Okolo, P.U. \& Anekwe, R.I. (2016). Multinational corporation and their effect on Nigerian economy. European Journal of Business and Management, 8(9), 22-30.

Enwereuzor, A. O. (2008). Theoretical approach to the study of multinational in the world system. African Journal, $6(4), 67-70$.

Ikelegbe, A. (2005). The economy of conflict in the oil rich Niger delta of Nigeria. Journal of African Studies, 14(2), 65-88.

Isike, C. (2004). Emerging threats in the Niger Delta and third world security conception: Implication for Nigeria's national security. In orobator, E. et al (eds) Federal, State and Resource Control in Nigeria. Parker Publishing Company. 
Jones, R. (2016). Private foreign and economic development: A case study of petroleum in India: Cambridge University Press.

Kodjo, S. (2010). Problem of private and public investment in Nigeria: Reading in social sciences issues in the national development. Edited by American, fourth dimension publications, Enugu.

McCulla, H. \& Shelly, B. (2015). The unemployment rate at full employment: How low can you go? New York Times.

Odogbor, P. O. (2004). Effect of environmental degradation on cultural heritage of the Niger Delta and the implication on sustainable rural development. In Orobator, E. et al (eds), Federal, State and Resource Control in Nigeria. F. Parker Publishing Company.

Ogbogbo, C.B.N. (2005). The Niger Delta people and the resource control conflict, 1960-1995: An assessment of conflict handling styles. In Albert, I. O. (ed) perspectives on peace and conflict in africa: Essays in honour of general (Dr) Abdulsalami A. Abuakar. Ibadan: Peace and Conflict Studies Programme.

Omotola, J. S. (2006). The next gulf? Oil politics, environmental apocalypse and rising: Tension in the Niger Delta. African centre for the constructive resolution of disputes (ACCORD), Occasional Paper Series, 1(3), 66-75.

Onodugo, V.A. (2013). Multinational corporations and employment and labour conditions of developing countries: The Nigerian experience. European Journal of Business and Social Sciences, 1(6), 67-76.

Onuoha, B. (2005). The role of indigenous MNCS in economics development in ideas in development: $A$ multidisciplinary overview edited by Okeke et al. Creative Education Management Consultant.

Osagwwu, G.O. \& Ezie, O. (2013). Multinational corporations and the Nigerian economy. International Journal of Academic Research in Business and Social Sciences, 3(4).

Peru, W. (2016). The effect of openness on economic growth for BRIC-T Countries: Panel data analysis. Eurasian Journal of Business and Economics, 6 (11), 1-14.

Rugman, N. \& Collinson, K. (2019). Multinational in a changing environment: A study of business government relationship in the third world. Fraeger Limited.

Tejvanne, P. (2013). New Trade Theory. Prentice Publication.

Udensi, E.U. (2015). The impact of multinational corporation to the Nigerian economy. International Journal of Social Science and Humanities Research, 3(2), 107-115.

UNCTAD, (2000). Capital flows and growth in Africa. UNCTAD/GDS/MDPB/7, New York and Geneva: United Nations.

Wilczynski M. (2016). Effect of multinational corporation on development of an Africa economy. The case of Nigeria. USA Activity Press. 